\title{
Recurrent Cerebellar Desmoplastic/Nodular Medulloblastoma in Cerebrospinal Fluid (CSF) in the Elderly. A Cytologic Diagnosis
}

\author{
ALEXANDRA KALOGERAKI ${ }^{1}$, DIMITRIOS TAMIOLAKIS ${ }^{1}$, PANAGIOTA MAVRIGIANNAKI ${ }^{2}$, MICHAEL KARVELAS- \\ KALOGERAKIS $^{1}$, GALATEIA DATSERI ${ }^{1}$, SOPHIA AGELAKI ${ }^{3}$, SAVVAS PAPADOPOULOS ${ }^{2}$ \\ ${ }^{1}$ Department of Pathology-Cytopathology, Medical Faculty, University of Crete, Greece \\ ${ }^{2}$ Department of Pathology, Hygeia Hospital, Athens, Greece \\ ${ }^{3}$ Department of Oncology, Medical Faculty, University of Crete, Greece
}

\begin{abstract}
Desmoplastic medulloblastoma is a rare subtype of medulloblastoma in childhood and more rare in adults. Cerebrospinal fluid (CSF) occurrence is frequent and important for treatment and prognosis. We report the CSF cytologic features of recurrent desmoplastic/ nodular medulloblastoma in a 30 -aged male.
\end{abstract}

Key words: Desmoplastic medulloblastoma, histopathology, cytopathology.

\section{INTRODUCTION}

Medulloblatoma (MB) is an embryonal malignnancy of the cerebellum in the roof of the forth ventricle, occurring in children, with neuronal differentiation (1). It comprises $0.4-1 \%$ of $\mathrm{CNS}$ neoplasms in adults [1-3], within the 21-40 year range, with a male predominance [4].

In WHO classification 2007 [5, 6], MB is categorized into classic (non-desmoplastic), desmoplastic/nodular, MB with extensive nodularity, and large cell anaplastic. Immunohistochemistry is useful to characterize subtypes of MB.

Cytologic findings have been rarely reported [7-9]. The monomorphic population of round cells, the presence of Homer-Wright_rosettes and the synaptophysin or S-100 expression, are diagnostic criteria.

Desmoplastic MB shows distinctive cytology in intraoperative smears. The occurrence in adults and the presence of astroglial elements in imprint smears cause a misinterpretation as gliomas [10].

\section{CASE REPORT}

A 30-year-old male, diagnosed at Hygeia Hospital of Athens of a desmoplastic/nodular MB of cerebellum (Figure 1), initially treated by total surgical resection, followed by craniospinal radiation and chemotherapy, presented at University Hospital of Heraklion for follow-up. He was disease free for 12 years. MRI revealed involvement of the lepto- meninges by tumor mass. A CSF sample from the ventricoperitoneal (VP) shunt was obtained. Papanicolaou and Giemsa-stained cytospin smears showed red blood cells, lymphocytes, histiocytes and single or paired (Figure 2) small neoplastic cells. Cell contours were rounded, or polygonal. Nuclei were single, irregular, with coarse granular chromatin. with a small amount of cytoplasm. No cell cannibalism, no mitoses were found.

Cells were positive for synaptophysin (Figure 3) and S-100 (Figure 4), while negative for glial fibrillary acidic protein (GFAP) and leukocyte common antigen (LCA), findings consistent with MB.

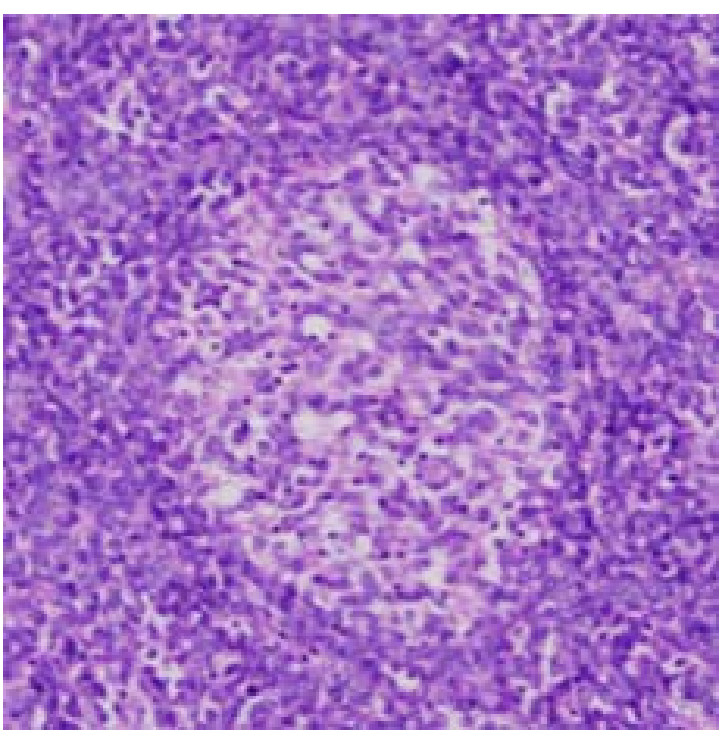

Figure 1. Desmoplastic Medulloblastoma. Histology. Hematoxylene-Eosin X 200. 


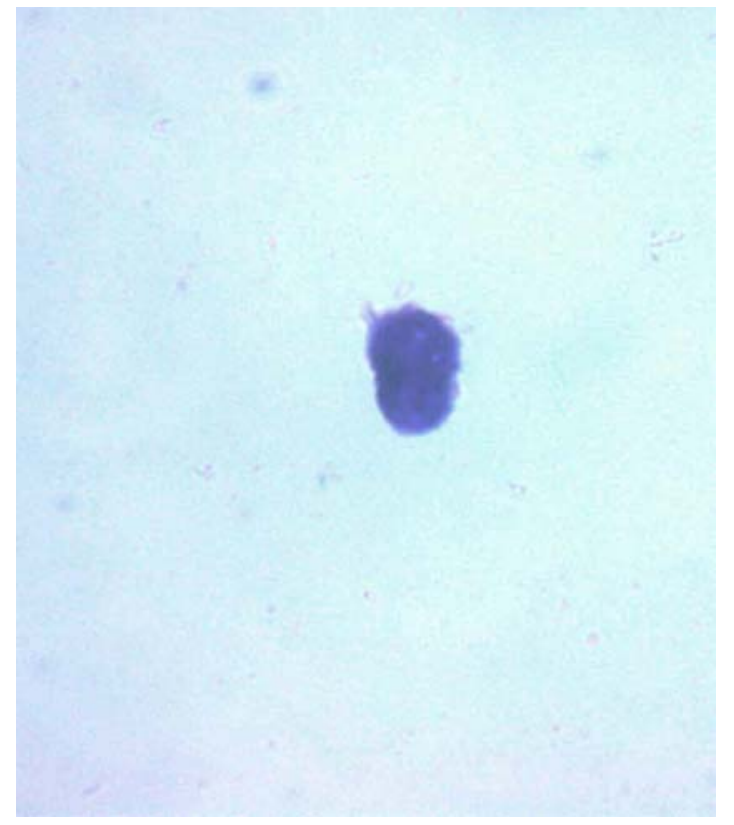

Figure 2. Desmoplastic Medulloblastoma. Cytology. Giemsa X 400.

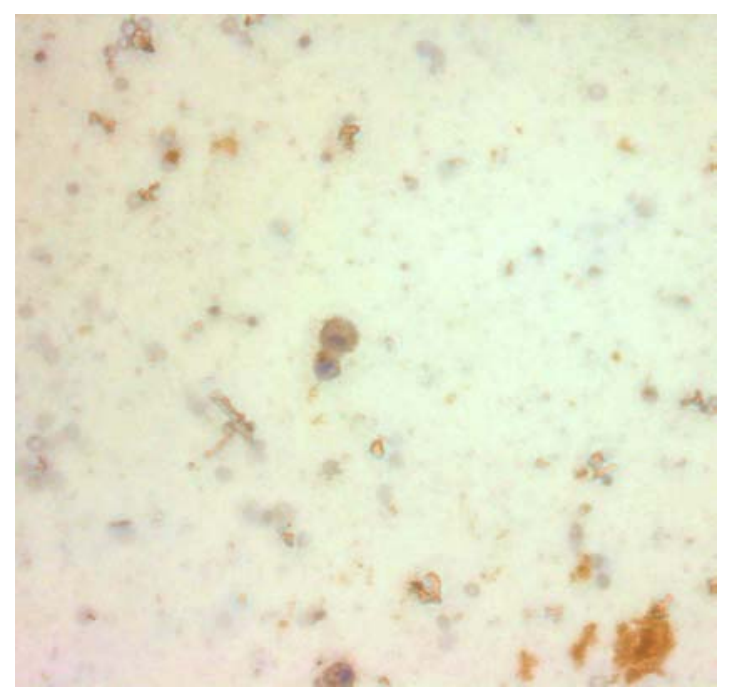

Figure 3. Desmoplastic Medulloblastoma. Cytology. Synaptophysin X 400 .

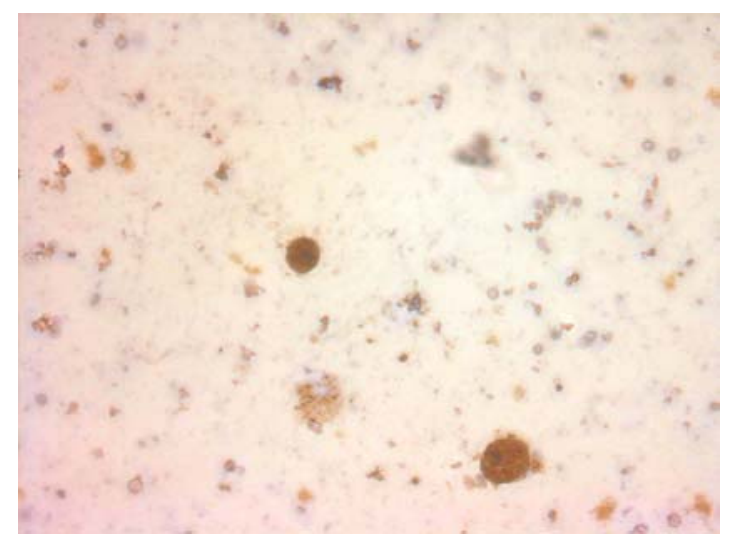

Figure 4. Desmoplastic Medulloblastoma. Cytology. S-100 X 400.
Then multiple biopsies of the tumor were performed and histology confirmed the cytologic diagnosis. In biopsy specimens based on the features in hematoxyline/eosine and reticulin stained sections, desmoplastic medulloblastoma was diagnosed when having a biphasic architecture that consisted of regions with dense intercellular reticulin and nodular reticulin-free zones, within which tumor cells show a neurocytic phenotype. Nitrosoureabased chemotherapy was reserved. The patient is disease free, by MRI, three months after recurrence.

\section{DISCUSSION}

Cytologic features of MBs have been studied in intraoperative smears. In CSF, cells are singly or in groups and show mild variability in size. In our case cells were singly small round and uniform. Rarely the Homer-Wright rosettes f are present [11, 12]. MB falls in the group of so-called small blue round cell tumors. Differential diagnosis includes lymphomas and sarcomas. MBs may show astrocytic differentiation. Classic MB may be misinterpreted as lymphoblastic lymphoma [13]. Immunocytochemistry is helpful. In our case cells were positive by synaptophysin and S-100 but negative by GFAP and LCA.

The recurrence rate for medulloblastomas in adults is approximately $50 \%$ to $60 \%$. The median time-to-tumor progression (TTP) is approximately 30 months, and the median survival after recurrence has been reported to be approximately 1.3 years. The most common site of recurrence is the posterior fossa. Other sites of recurrence include the spine, CSF, supratentorial cerebrum, bone, and other extraneural sites. Late recurrences are more common in adults than in children. In one study, $59 \%$ of all recurrences occurred more than 2 years after treatment, whereas, in general, $75 \%$ of childhood medulloblastoma recurrences occur within the first 2 years after treatment. Recurrences as late as 14 years after treatment have been reported. Thus, long-term monitoring is important for adult medulloblastoma patients $[14,15]$.

CSF cytologic analysis has been reported to have limited sensitivity in detecting neoplastic infiltration. For primary neoplasms of the CNS with histologically confirmed meningeal involvement, the percentage of positive CSF cytologic results has been reported to range from $12 \%$ to $37 \%$. The percentage of positive CSF cytologic results is notably higher for medulloblastoma, ranging from $43 \%$ to $62 \%$. The higher percentage 
of positive CSF cytologic results for medulloblastoma compared with other CNS neoplasms may result from the location of the primary lesions near the pial surface and tumor composition of loosely bound malignant cells that can readily exfoliate once they invade the meninges [16].

Fouladi et al. [17] reported that results from CSF cytologic analysis or spinal MR imaging alone missed the diagnosis of disseminated medullo- blastoma in the initial postoperative evaluation in $14 \%$ and $18 \%$, respectively. Spinal MR imaging has greater diagnostic accuracy than CSF cytologic analysis in the early detection of disseminated tumor. The sensitivity of CSF cytologic analysis increases with acquisition of multiple subsequent samples.

Declaration of interest: The authors do not declare any conflict of interest.

Meduloblastomul desmoplastic este un subtip rar al meduloblastomului care apare mai frecvent la copii decât la adulți. Prelevarea de lichid cefalorahidian $(L C R)$ este importantă pentru tratamentul pacienților şi prognosticul acestora. In această prezentare de caz sunt raportate caracteristicile citologice LCR ale unui pacient în vârstă de 30 de ani ce a avut o recidivă a unui meduloblastom tratat.

Correspondence to: Assoc. Professor Dr. Alexandra Kalogeraki, University of Crete, Medical Faculty, Greece E-mail: kalogerakimed@yahoo.gr

\section{REFERENCES}

1. PACKER RJ, MACDONALD T, VEZINA G, KEATING R, SANTI M. Medulloblastoma and primitive neuroectodermal tumors. Handb Clin Neurol. 2012; 105:529-48.

2. CHHIENG DC, ELGERT P, COHEN JM, JHALA NC, CANGIARELLA JF. Cytology of primary central nervous system neoplasms in cerebrospinal fluid specimens. Diagn Cytopathol. 2002 Apr; 26(4):209-12.

3. KLUGE HARALD, WIECZOREK VALENTIN, LINKE ERNST, ZIMMERMANN KLAUS, ISENMANN STEFAN, WITTE OTTO W. Atlas of CSF Cytology. Stuttgart: Thieme; 2007; 84-7.

4. HUPPMANN AR, ORENSTEIN JM, JONES RV. Cerebellar medulloblastoma in the elderly. Ann Diagn Pathol. 2009 Feb;13(1):55-9.

5. PRADNIWAT K, CHEUNSUCHON P, SANGRUCHI T. Histopathological subtypes of medulloblastoma according to WHO classification (2007): An 8-year retrospective study. Siriraj Med J 2010; 62: 202-205

6. F.GIANGASPERO, C.G. EBERHART, H. ELLISON DW,HAAPASALO H, PIETSCH T, WIESTLAR OD. Medulloblastoma. In: D.N. Louis, H. Ohgaki, O.D. Wiestler, W.K. Cavanee eds. WHO Classification of Tumours of the Nervous System IARC, Lyon, 2007. p. 132-140.

7. BALIGA M, HOLMQUIST ND, ESPINOZA CG. Medulloblastoma metastatic to breast, diagnosed by fine-needle aspiration biopsy. Diagn Cytopathol. 1994; 10(1):33-6.

8. NGUYEN GK, JOHNSON ES, MIELKE BW. Cytology of neuroectodermal tumors of the brain in crush preparations. A review of 56 cases of deep-seated tumors sampled by CT-guided stereotactic needle biopsy. Acta Cytol. 1989 Jan-Feb; 33(1):67-73.

9. SHAH AB, MUZUMDAR GA, CHITALE AR, BHAGWATI SN. Squash preparation and frozen section in intraoperative diagnosis of central nervous system tumors. Acta Cytol. 1998 Sep-Oct; 42(5):1149-54.

10. RIAZMONTAZER N, DANESHBOD Y. Cytology of desmoplastic medulloblastoma in imprint smears: A report of 2 cases. Acta Cytol 2006; 50:97-100.

11. TAKEI H, DAUSER RC, ADESINA AM. Cytomorphologic characteristics, differential diagnosis and utility during intraoperative consultation for medulloblastoma. Acta Cytol 2007; 51:183-192.

12. DHALL G. Medulloblastoma. J Child Neurol. 2009 Nov; 24(11):1418-30.

13. NELSON AC, SINGH C, BRENT CLARK H, PAMBUCCIAN SE. Recurrent anaplastic medulloblastoma in cerebrospinal fluid after autologous hematopoietic stem cell transplant. Diagn Cytopathol. 2013 Nov; 41(11):980-5.

14. PAN E, PRADO M. Adult Medulloblastomas. In: Holland-Frei Cancer Medicine. $6^{\text {th }}$ edition. Kufe DW, Pollock RE, Weichselbaum RR, et al., editors. Hamilton (ON): BC Decker; 2003.

15. CIUREA AV, PALADE CL. Medulloblastoma - An overview. Romanian Neurosurgery 2010; 17(3): 291-303.

16. MEYERS SP, WILDENHAIN SL, CHANG JK, BOUREKAS EC, BEATTIE PF, KORONES DN et al. Postoperative evaluation for disseminated medulloblastoma involving the spine: contrast-enhanced MR findings, CSF cytologic analysis, timing of disease occurrence, and patient outcomes. AJNR Am J Neuroradiol. 2000 Oct; 21(9):1757-65.

17. FOULADI M, GAJJAR A, BOYETT JM, et al. Comparison of CSF cytology and spinal magnetic resonance imaging in the detection of leptomeningeal disease in pediatric medulloblastoma or primitive neuroectodermal tumor. J Clin Oncol 1999; 17:3234-7. 